\title{
Sistem Informasi Pendataan Penduduk Pendatang Kecamatan Tegallalang
}

\author{
I Made Sudibya ${ }^{1}$, I Made Prabu Krisna Pradnya S. S. ${ }^{2}$, \\ I Gede Suardika ${ }^{3}$, I Gusti Ngurah Ady Kusuma ${ }^{4}$ \\ 1,2,3,4 Institut Teknologi dan Bisnis STIKOM Bali \\ e-mail: sudibya@ stikom-bali.ac.id ${ }^{1}$,prabukrisna@stikom-bali.ac.id.2, \\ suardika.stikom@gmail.com ${ }^{3}$, ady_kusuma@stikom-bali.ac.id ${ }^{4}$
}

\begin{abstract}
Abstrak
Kecamatan Tegallalang yang terdapat di Kabupaten Gianyar Provinsi Bali masih banyak menggunakan proses pendataan penduduk secara manual sehingga terjadi penumpukan berkas dan memicu terjadinya kehilangan berkas surat ijin. Dari sana munculah ide penulis untuk membuat sebuah Sistem pendataan penduduk pendatang Kecamatan Tegallalang menggunakan metode waterfall. Sistem informasi pendataan penduduk pendatang ini diimplementasikan dalam bentuk website. Sistem informasi ini dibangun dengan menggunakan bahasa pemograman PHP, DataBase MySQL dan Codeigniter sebagai framework. Adapun cara pengujian progam ini menggunakan metode blackbox. Telah dihasilkan sebuah system informasi yang dapat mempermudah pendataan penduduk pendatang di kecamatan Tegallalang. Berdasarkan pengujian blackbox sistem yang dihasilkan berjalan dengan baik.
\end{abstract}

Kata kunci-Kantor Camat Tegallalang, Penduduk Pendatang, Sistem

\begin{abstract}
Tegallalang sub-district in Gianyar regency still uses the population data collection process manually so that there is an accumulation of files and triggers the loss of permit documents. From there came the writer's idea to create a data collection system for migrants in Tegallalang District. The author conducts research into the Tegallalang District office by using the waterfall method, the authors collect data by conducting interviews directly to Tegallalang District officials. This migrant population information system is implemented in the form of a website. This information system will be built using the PHP programming language and processed using MySQL DataBase and Codeigniter as a framework. As for how to test this program using the blackbox method in which the author tries one by one the menu contained in this information system. So as to produce a program that can facilitate the data collection system of migrants in Tegallalang sub-district. Based on blackbox testing the resulting system runs well.
\end{abstract}

Keywords - Tegallalang Sub-District Office, Migrant Residents and Systems

\section{PENDAHULUAN}

Penduduk pendatang adalah penduduk yang menetap pada suatu daerah / Negara yang bukan merupakan penduduk asli dari daerah / negara tersebut. Contohnya seperti penduduk pendatang dari daerah Jawa, Sulawesi, Kalimantan yang tinggal di Bali[1].

Saat ini penduduk pendatang di kecamatan Tegallalang sangat banyak, terutama pada desa Kedisan, Keliki, Taro dan Pupuan. Ini dapat dibuktikan dari banyaknya penduduk luar 
daerah yang penulis jumpai di Desa Kedisan, Keliki, Taro dan Pupuan. Hal ini tentu menyebabkan pendataan penduduk di kecamatan Tegallalang menjadi tidak berjalan sebagai mana mestinya. Hal ini dikeranakan proses pendataan penduduk di kecamatan Tegalalang masih menggunakan proses manual, sehingga penduduk pendatang enggan untuk melakukan proses pengurusan surat ijin tinggal karena prosesnya yang panjang dan cukup lama. Penduduk pendatang juga enggan mengurus surat ijin tinggal karena mereka tidak ingin bolak-balik ke kantor kecamatan untuk melengkapi berkas yang masih kurang. Selain itu pada kecamatan Tegallalang sering terjadi penumpukan berkas dan juga duplikasi berkas yang menyebabkan data penduduk pada kecamatan Tegallalang menjadi salah.

Penduduk pendatang yang tidak memiliki surat ijin tinggal ditakutkan nantinya mereka bertindak seenaknya seperti mencuri dan tindakan kejahatan lainya karena data-data mereka tidak terdaftar di kecamatan Tegallalang. Selain itu pendatang yang setiap bulannya semakin meningkat bisa saja menyebabkan kepadatan penduduk di kecamatan Tegallalang, karena bebasnya penduduk pendatang yang masuk di kecamatan Tegallalang.

Diperlukan sebuah sistem informasi untuk mempermudah proses pendataan penduduk. Dimana sistem informasi berbasis website yang paling cocok digunakan di kantor kecamatan. Karena sistem informasi berbasis website lebih mudah digunakan oleh banyak orang, baik petugas kecamatan maupun penduduk pendatang. Sistem informasi berbasis website sendiri adalah kumpulan informasi yang diolah agar menjadi sebuah informasi yang akurat dimana informasi tersebut diolah pada sebuah website. Website yang dibangun akan menggunakan CodeIgniter sebagai framework dan pembuatan Database menggunakan MySQL dan beberapa software pendukung lainya seperti Bootstrap, XAMPP dan Google Maps dimana nantinya jika website sudah dibangun akan diuji coba dengan menggunakan metode balckbox testing, dimana pengujian dengan metode ini dilakukan dengan cara mencoba satu persatu menu-menu yang terdapat di dalam program sistem informasi ini. Selain itu sistem informasi berbasis website ini akan dibangun menggunakan metode Waterfall. Metode waterfall ini mempermudah dalam proses membangun sebuah sistem informasi.

Dengan dibuatkannya sebuah sistem informasi, diharapkan dapat mempermudah proses yang panjang dalam mengurus pendataan penduduk, sehingga penduduk pendatang yang jarak tempat tinggalnya jauh dari kantor kecamatan Tegallalang dapat dipermudah dengan hanya mengakes web, karena semua proses sudah berjalan secara online. Nantinya setiap data diri yang diinputkan dari web tersebut akan langsung masuk ke database kantor kecamatan Tegallalang, maka penduduk pendatang hanya perlu meminta tanda tangan dari kepala kantor Kecamatan Tegalalang sebagai tanda pengesahan surat ijin tinggal.

Berdasarkan pemaparan latar belakang diatas, maka penulis mengangkat judul "Sistem Informasi Pendataan Penduduk Pendatang Kecamatan Tegallalang".

\section{METODE PENELITIAN}

\subsection{Metode Pengumpulan Data}

Tahap pertama dari penelitian ini adalah dengan melakukan pengumpulan data. Adapun metode yang penulis gunakan dalam pengumpulan data yaitu studi literatur, observasi, wawancara, dan kuesioner.

a. Studi Literatur

Studi literatur merupakan metode pengumpulan data dengan cara menelusuri dan mempelajari literatur yang bersumber dari buku, media, pakar maupun hasil penelitian yang sudah pernah dilakukan sebelumnya yang bertujuan untuk menyusun dasar teori dalam melakukan penelitian ini.

b. Observasi

Observasi dilakukan oleh penulis dengan cara melakukan pencarian langsung terhadap penduduk pendatang yang ada di Kecamatan Tegallalang dan melakukan dokumentasi terhadap penduduk pendatang, serta untuk mendapatkan koordinat yang sesuai. 
c. Wawancara

Wawancara merupakan metode pengumpulan data dengan cara bertanya kepada pihak-pihak yang terkait dalam hal ini yaitu petugas kecamatan dan penduduk pendatang. Wawancara ini dilakukan untuk memperoleh informasi mengenai informasi proses pendataan penduduk tersebut.

d. Kuesioner

Metode ini dilakukan dengan melibatkan 11 orang responden yaitu 1 petugas kecamatan serta 10 penduduk pendatang. Kuesioner ini terdiri dari 10 pertanyaan dengan nilai Sangat Setuju, Setuju, Cukup Setuju, Tidak Setuju, Sangat Tidak Setuju. Sebelum mengisi kuesioner, para responden akan mencoba menggunakan sistem untuk melakukan pendataan penduduk. Data yang telah diperoleh nantinya akan diolah untuk mengetahui tingkat efektifitas dari Sistem Informasi Pendataan Penduduk Kecamatan Tegallalang. Kuesioner dikatakan berhasil apabila sistem ini efektif dan mudah digunakan oleh pengguna dalam melakukan pendataan penduduk pendatang pada kecamatan Tegallalang.

\section{2 Metode Pengembangan Perangkat Lunak}

Dalam perekayasaan sistem, metode yang penulis gunakan untuk Rancang Bangun Sistem Informasi Pendataan Penduduk Kecamatan Tegallalang adalah dengan menggunakan metode Waterfall. Metode waterfall adalah metode klasik yang bersifat sistematis, berurutan dalam membangun software [3]. Disebut metode waterfall karena tahap demi tahap yang dilalui harus menunggu selesainya tahap sebelumnya dan berjalan berurutan. Pengembangan dengan metode Waterfall dilakukan dengan lima tahap, yaitu Analisis Kebutuhan (requirement), Desain Sistem (design), Implementasi Sistem (implementation), Pengujian Sistem (testing), dan Pemeliharaan Sistem (maintenance).

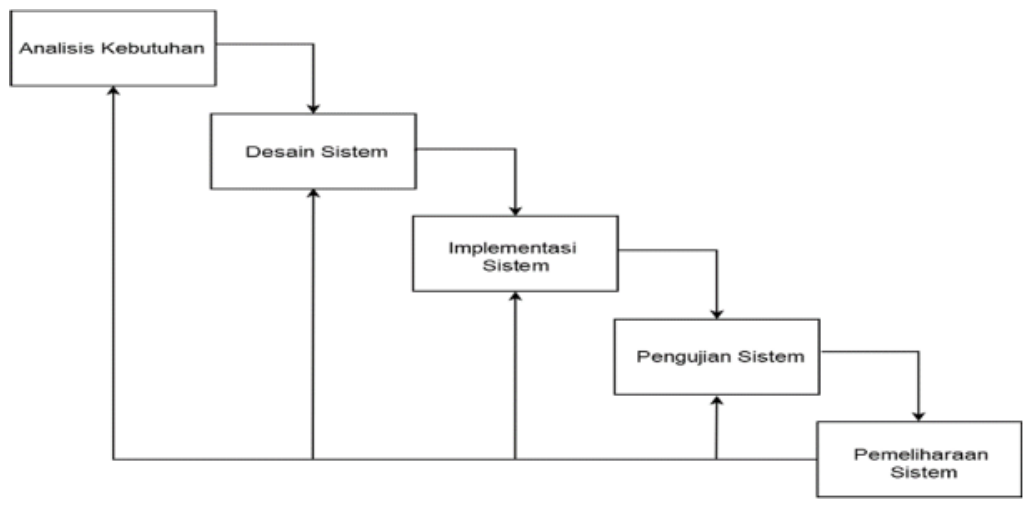

Gambar 1 Metode Waterfall

\section{HASIL DAN PEMBAHASAN}

\subsection{Analisa dan Perancangan Sistem}

Analisa sistem adalah penguraian dari suatu sistem informasi yang utuh ke dalam bagian-bagian komponennya dengan maksud untuk mengidentifikasikan dan mengevaluasi permasalahan, hambatan yang terjadi serta kebutuhan yang diharapkan sehingga dapat diusulkan perbaikannya [4]. Tujuan dari analisa sistem yaitu mempelajari suatu sistem untuk menganalisa masalah yang terdapat pada sistem tersebut. Selain itu, tujuan lain dari analisa sistem yaitu menyusun suatu tahap rencana pengembangan sistem. 
Perancangan sistem yang digunakan dalam sistem informasi pendataan penduduk pendatang kecamatan Tegallalang yaitu Flowchart, ERD (Entity Relationship Diagram) dan DFD (Data Flow Diagram).

\subsubsection{Analisa Kebutuhan Fungsional}

Kebutuhan fungsional adalah kebutuhan yang berisi proses-proses atau layanan apa saja yang nantinya harus disediakan oleh sistem. Kebutuhan fungsional harus dapat menggambarkan layanan apa saja yang bisa diberikan oleh sistem kepada pengguna secara detail.

1. Analisa Kebutuhan Fungsional Penduduk Pendatang

- $\quad$ Melakukan login penduduk

- $\quad$ Menginput biodata

- Menginput Formulir Permohonan surat izin

- $\quad$ Mensubmit formulir surat izin

- $\quad$ Mengecek status permohonan surat izin

- $\quad$ Mengunduh dan mencetak surat izin yang sudah di setujui oleh admin kecamatan

Analisa Kebutuhan Fungsional Admin Kecamatan

- $\quad$ Melakukan regristrasi username dan password untuk penduduk.

- $\quad$ Mengedit data admin

- $\quad$ Melihat detail permohonan surat izin tinggal dari penduduk pendatang.

- $\quad$ Mengelola permohonan surat izin (cari, proses, hapus, cetak).

- $\quad$ Menyetujui permohonan surat izin tinggal.

- $\quad$ Mengirim email konfirmasi kepada penduduk pendatang.

- $\quad$ Mengecek masa berlaku surat izin tinggal penduduk pendatang.

- $\quad$ Melihat lokasi penduduk pendatang melalui sistem.

- $\quad$ Mengirim notifikasi untuk melakukan perpanjangan surat izin

\subsubsection{Analisa Kebutuhan Non Fungsional}

Kebutuhan non fungsional adalah batasan layanan atau fungsi yang ditawarkan sistem seperti batasan waktu, batasan pengembangan proses, standarisasi, dan lain-lain. Analisa kebutuhan non fungsional dilaksanakan untuk mengetahui spesifikasi kebutuhan untuk sistem. Spesifikasi kebutuhan tersebut dapat meliputi analisa perangkat keras (hardware), analisa perangkat lunak (software), dan analisa pengguna (user).

1. Analisa Perangkat Keras (Hardware)

a. Processor : $\quad$ Intel Core i7-4720HQ @ 2.60GHz

b. RAM : $8 \mathrm{~GB}$

c. Harddisk : $1 \mathrm{~TB}$

2. Analisa Perangkat Lunak (Software)
a. $\quad X A M P P($ Apache, $M y S Q L)$
b. Visual Studio Code
c. Web Browser

3. Analisa User
a. Admin Kecamatan
b. Penduduk Pendatang

\subsubsection{Flowchart}

Flowchart urutan prosedur yang dapat menggambarkan aktivitas apa saja yang bisa dilakukan oleh sistem sehingga cara kerja sistem tersebut dapat dipahami secara keseluruhan. 


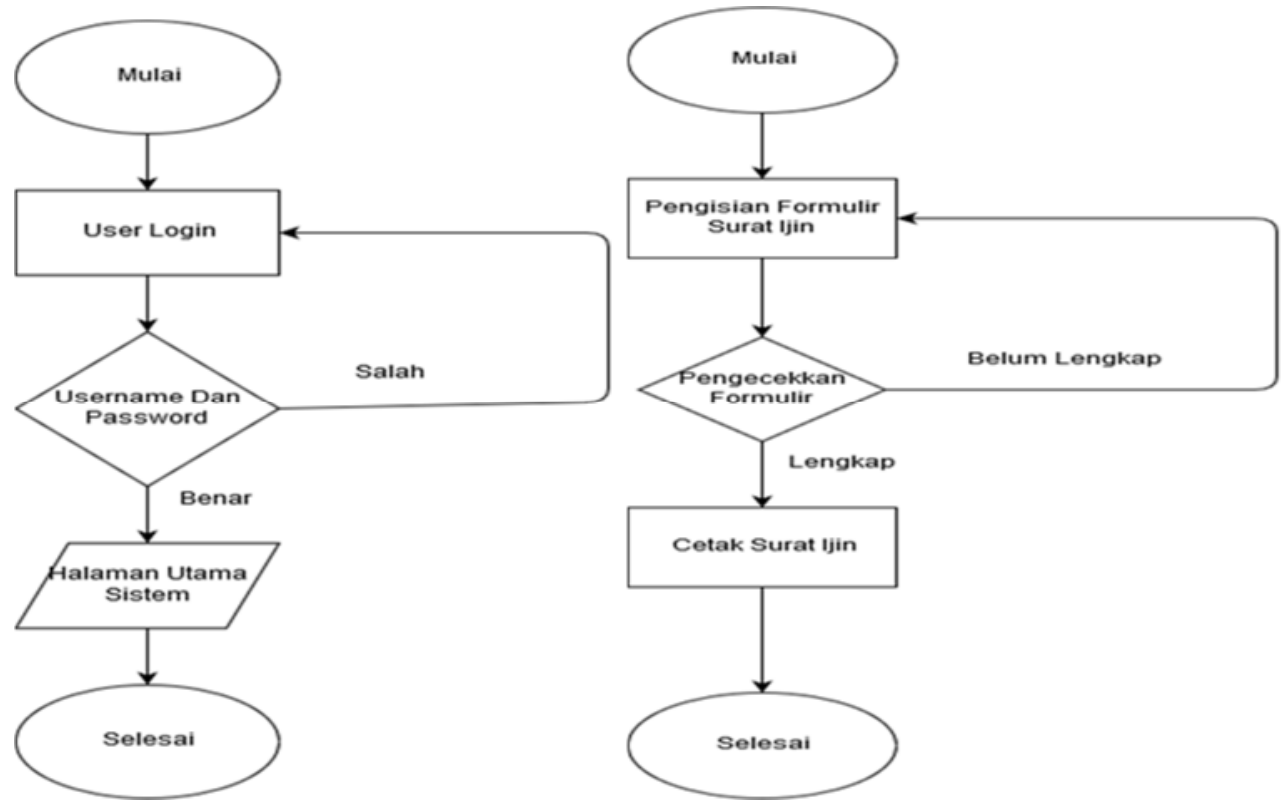

Gambar 2 Flowchart

\subsubsection{Diagram Konteks}

Diagram konteks adalah diagram yang terdiri dari suatu proses dan menggambarkan ruang lingkup serta konsep dasar pengembangan suatu sistem. Diagram konteks ini merupakan bagian tertinggi dari DFD (Data Flow Diagram) yang menggambarkan seluruh input ke dalam suatu sistem dan output dari sistem.

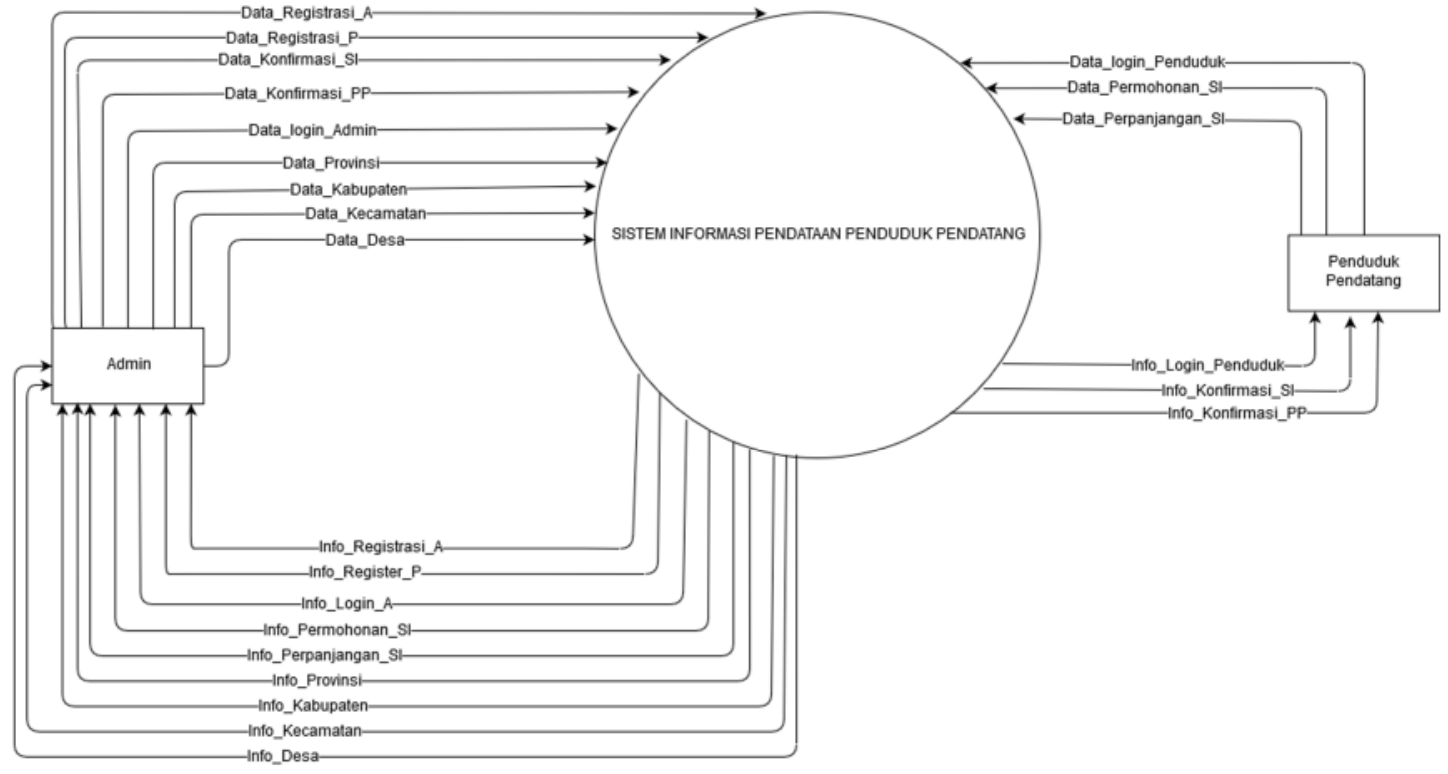

$\mathrm{A}=$ Admin
$\mathrm{P}=$ Penduduk

$P=$ Penduduk
SI = Surat liin

$\mathrm{PP}=$ Perpanjangan

Gambar 3 Diagram Konteks 


\subsubsection{DFD Level 0}

DFD (Data Flow Diagram) level 0 merupakan pemecahan atau penjabaran dari diagram konteks. DFD (Data Flow Diagram) level 0 menunjukkan sistem data secara keseluruhan serta menekankan cara sistem berinteraksi dengan entitas luar.
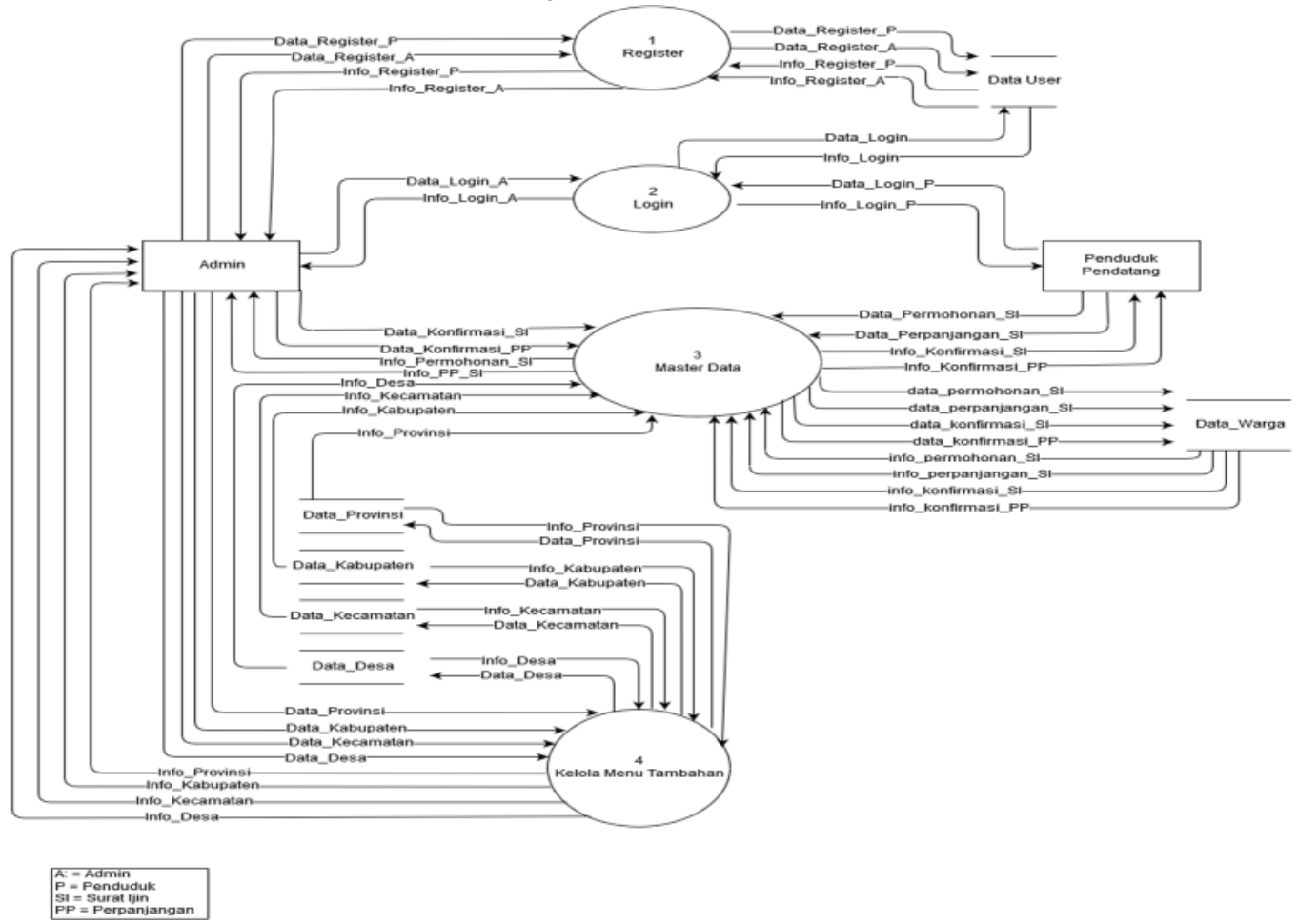

Gambar 4. DFD Level 0

\subsubsection{ERD (Entity Relationship Diagram)}

ERD (Entity Relationship Diagram) adalah salah satu metode pemodelan basis data yang digunakan untuk menghasilkan skema konseptual untuk jenis atau model data semantik sistem dimana sistem seringkali memiliki basis data relasional.

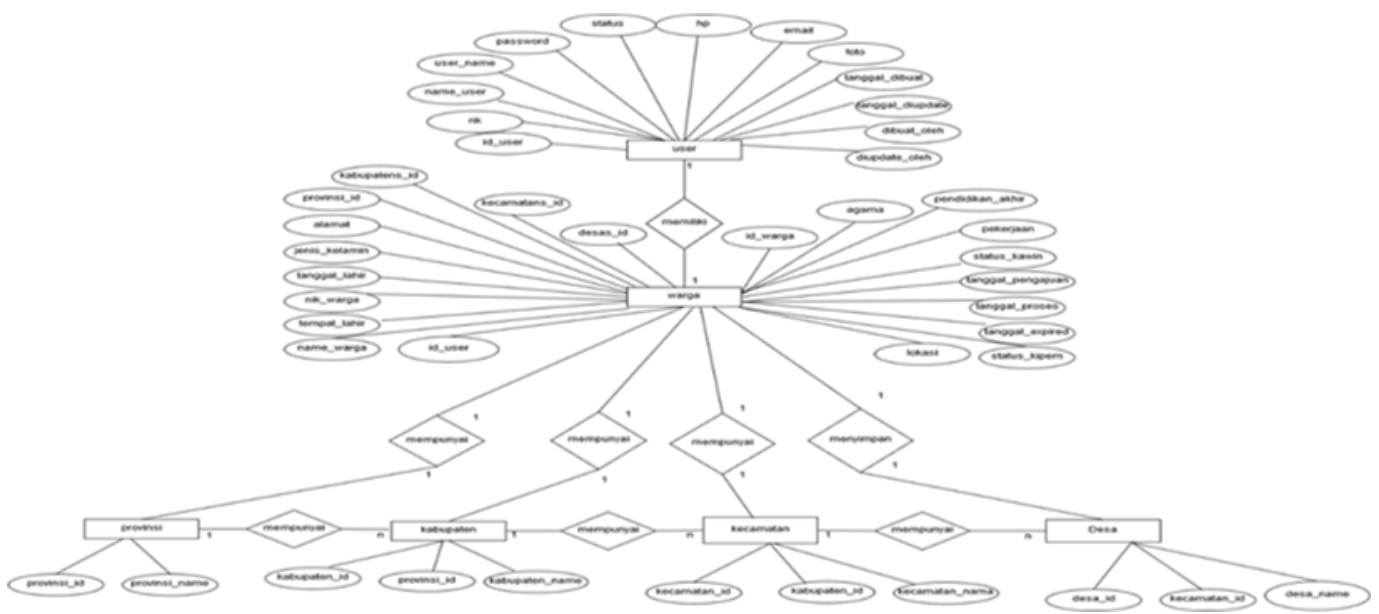

Gambar 5. ERD (Entity Relationship Diagram) 


\subsubsection{Implementasi Halaman Admin}

Pada implementasi halaman admin akan menampilkan halaman yang hanya dapat diakses oleh admin. Untuk dapat masuk ke halaman admin, maka admin harus melakuka login terlebih dahulu. Berikut ini adalah tampilan dari halaman admin dari sistem informasi pendataan penduduk pendatang kecamatan tegallalang.

1.Halaman Utama Admin

Dalam halaman utama admin menampilkan tampilan awal ketika admin sudah melakukan login. Pada halaman utama admin akan menampilkan menu-menu untuk mengelola data permohonan, menyetujui permohonan, grafik, data user dan provinsi. Berikut tampilan dari halaman utama admin.

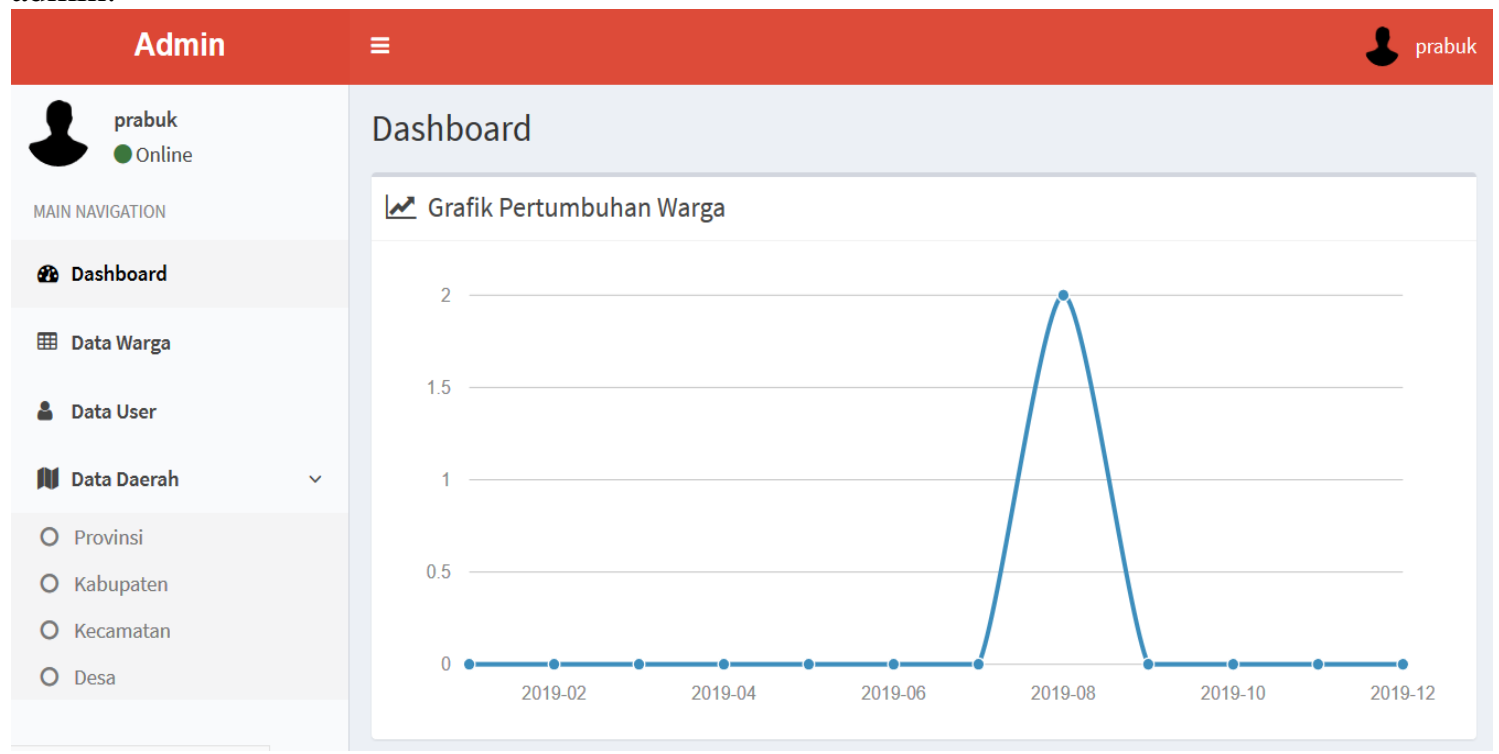

Gambar 6. Halaman Utama Admin

\section{Halaman Data Warga}

Dalam halaman data warga terdapat list permohonan yang belum diproses, halaman yang sudah disetujui dan halaman yang sudah expired. Berikut tampilan dari halaman data warga.

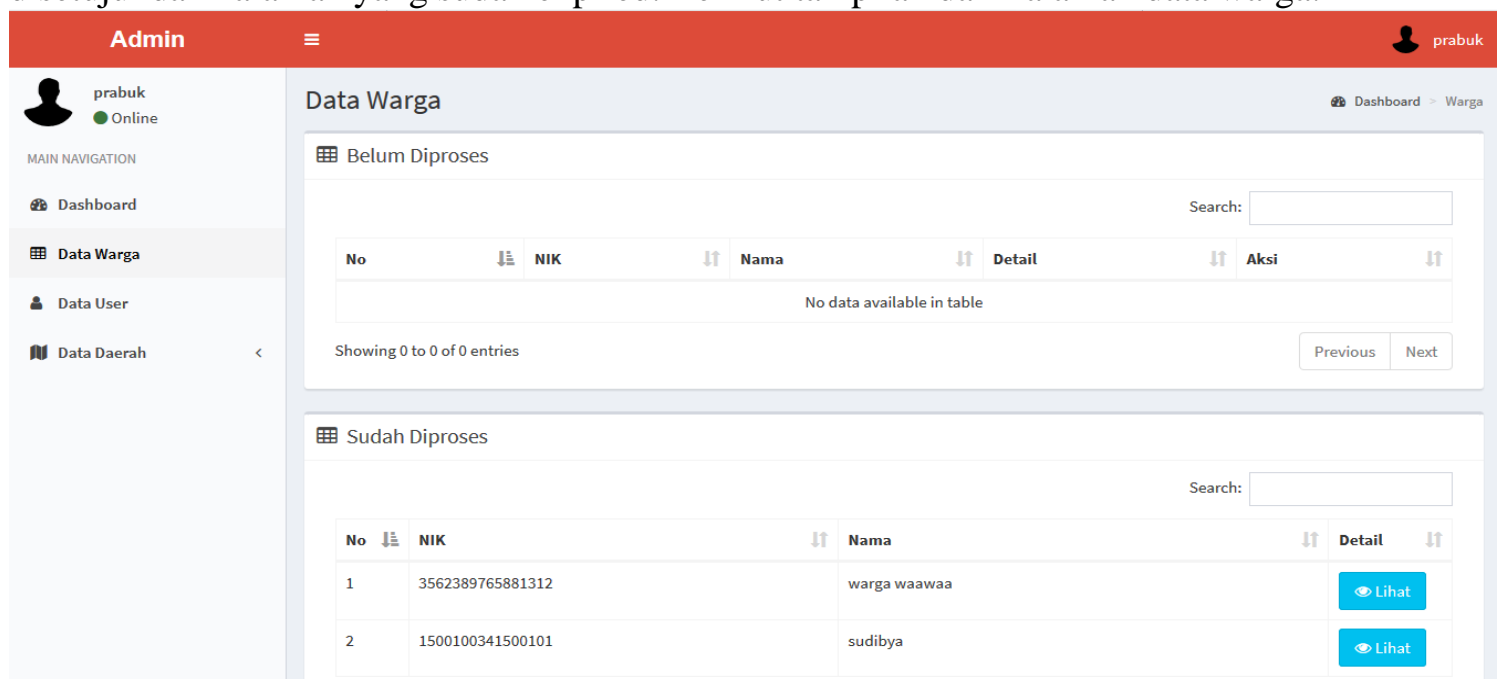

Gambar 7. Halaman Data Warga 


\subsubsection{Implementasi Halaman Penduduk}

Pada implementasi halaman penduduk akan menampilkan halaman penduduk. Untuk dapat masuk ke halaman penduduk, maka harus melakukan login terlebih dahulu. Untuk mendapatkan akun, maka harus dibuatkan user oleh admin terlebih dahulu.

1. Halaman Utama User Yang Belum Mengajukan Surat Ijin

Pada halaman ini, bagi user yang belum mengisi formulir sistem akan menampilkan secara otomatis peringatan untuk melengkapi formulir terlebih dahulu, berikut tampilan dari menu utama bagi user yang belum melengkapi surat izin.

\begin{tabular}{|c|c|}
\hline Warga & 3 sugitha \\
\hline $\int \begin{array}{l}\text { sugitha } \\
\text { Online }\end{array}$ & Dashboard \\
\hline MAIN NAVIGATION & i Informasi Pengajuan KIPEM \\
\hline Dashboard & Anda Belum Mengisi Formulir Pengajuan KIPEM, sialhkan ajukan terlebih dahulu ! \\
\hline
\end{tabular}

Copyright ๑ 2019. All rights reserved.

Gambar 8. Halaman Utama User Yang Belum Mengajukan Surat Ijin

2. Halaman Pengajuan Surat Ijin

Pada menu ini user harus lengkapi semua formulir yang terdapat pada surat izin ini, apabila user tidak melengkapi satu saja kolom formulir tersebut, maka secara otomatis sistem tidak akan bisa mensubmit formulir permohonan yang diajukan oleh user, berikut ini tampilan dari formulir pendaftaran surat izin.

\begin{tabular}{|c|c|c|c|}
\hline Warga & \multicolumn{2}{|l|}{$\equiv$} & 3 sugitha \\
\hline$\left\{\begin{array}{l}\text { sugitha } \\
\text { Online }\end{array}\right.$ & \multicolumn{2}{|l|}{ Pengajuan } & Dashboard > Pengajuan \\
\hline MAIN NAVIGATION & \multicolumn{3}{|l|}{ 国 Formulir Pengajuan KIPEM } \\
\hline Dashboard & Nama & NIK & \\
\hline \multirow{9}{*}{ I. Pengajuan } & sugitha & 9999999999999999 & \\
\hline & Tempat Lahir & Tanggal Lahir & \\
\hline & & 2019-08-13 & \\
\hline & Jenis Kelamin & Alamat & \\
\hline & Laki-laki & & \\
\hline & Provinsi & Pilih Kabupaten & \\
\hline & -Pilih Provinsi- & -Pilih Kabupaten- & \\
\hline & Pilih Kecamatan & Pilih Desa & \\
\hline & -Pilih Kecamatan- & -Pilih Desa- & \\
\hline
\end{tabular}




\subsection{Pengujian Sistem}

Teknik pengujian yang digunakan pada pengujian ini yaitu menggunakan Black-box testing. Black-box testing bertujuan untuk menguji input dan output dari sistem apakah sesuai dengan yang diinginkan.

\subsubsection{Black-Box Testing}

Berdasarkan pengujian menggunakan Black-Box Testing dapat disimpulkan bahwa seluruh item yang diuji disetiap halaman sudah sesuai dengan apa yang diharapkan. Pengujian program meliputi semua menu, button, textbox, dan edit text.

\subsubsection{Kuesioner}

Pengujian kuesioner dilakukan dengan menyebarkan lembar kuesioner yang terdiri dari 10 pertanyaan dan melibatkan 11 orang responden yang terdiri dari petugas kecamatan dan penduduk pendatang.

Tabel 1. Responden

\begin{tabular}{|c|c|c|c|c|}
\hline \multirow{2}{*}{ No. } & \multirow{2}{*}{ Responden } & \multicolumn{2}{|c|}{ Jenis Kelamin } & \multirow{2}{*}{ Jumlah } \\
\cline { 3 - 4 } & & Laki-Laki & Perempuan & \\
\hline 1. & Petugas Kecamatan & 1 & 0 & 1 \\
\hline 2. & Penduduk Pendatang & 6 & 4 & 10 \\
\hline \multicolumn{2}{|c|}{ Total Jumlah Responden } & 7 & 4 & 11 \\
\hline
\end{tabular}

Berikut ini merupakan rekapan hasil jawaban pernyataan kuesioner yang telah diisi oleh responden yang tertera pada Tabel 2 .

Tabel 2. Rekap Hasil Jawaban Pernyataan

\begin{tabular}{|c|c|c|c|c|c|c|c|c|c|c|}
\hline \multirow{3}{*}{ Responden } & \multicolumn{10}{|c|}{ Nomor Pernyataan dan Jawaban } \\
\hline & \multicolumn{2}{|c|}{$\begin{array}{c}\text { Segi } \\
\text { Kemudahan }\end{array}$} & \multicolumn{2}{|c|}{ Segi Konten } & \multirow{2}{*}{$\begin{array}{c}\text { Segi } \\
\text { Manfaat } \\
\text { P5 }\end{array}$} & \multicolumn{5}{|c|}{$\begin{array}{c}\text { Segi } \\
\text { Interface }\end{array}$} \\
\hline & P1 & P2 & P3 & P4 & & P6 & P7 & P8 & P9 & P10 \\
\hline R1 & SS & SS & SS & SS & SS & SS & SS & SS & SS & SS \\
\hline $\mathrm{R} 2$ & SS & $S$ & SS & SS & SS & SS & SS & SS & SS & SS \\
\hline R3 & SS & $S$ & SS & SS & $S$ & SS & SS & SS & SS & SS \\
\hline $\mathrm{R} 4$ & SS & SS & SS & SS & SS & SS & SS & SS & SS & SS \\
\hline $\mathrm{R5}$ & SS & SS & SS & SS & SS & SS & SS & SS & SS & SS \\
\hline $\mathrm{R} 6$ & SS & SS & SS & SS & SS & SS & SS & SS & SS & SS \\
\hline R7 & SS & SS & SS & $S$ & SS & SS & SS & SS & CS & SS \\
\hline R8 & SS & SS & SS & $S$ & SS & SS & $\mathrm{S}$ & SS & SS & SS \\
\hline R9 & SS & SS & SS & SS & SS & SS & $S$ & $S$ & SS & SS \\
\hline R10 & SS & SS & SS & SS & SS & SS & SS & SS & SS & $S$ \\
\hline R11 & $S$ & $S$ & SS & SS & SS & SS & SS & SS & SS & SS \\
\hline
\end{tabular}

Berikut ini merupakan hasil perhitungan kuesioner berdasarkan kategori segi kemudahan pada sistem, segi konten pada sistem, segi manfaat pada sistem dan segi interface pada sistem yaitu sebagai berikut :

$$
y=\frac{P}{Q} \times 100 \%
$$

Keterangan :

$\mathrm{y}=$ Nilai Persentase

$\mathrm{P}=$ Total Jawaban Responden Per Indikator Menurut Kriteria Nilai

$\mathrm{Q}=$ Total Jawaban Responden Per Indikator

Pada segi kemudahan, berdasarkan hasil perhitungan diatas $81.81 \%$ responden memberikan penilaian sangat setuju dan $18.18 \%$ responden memberikan nilai setuju. Pada segi 
konten, berdasarkan hasil perhitungan diatas $90.90 \%$ responden memberikan penilaian sangat setuju dan $9.90 \%$ responden memberikan nilai setuju. Pada segi manfaat, berdasarkan hasil perhitungan diatas $90.90 \%$ responden memberikan penilaian sangat setuju dan $9.90 \%$ responden memberikan nilai setuju. Pada segi interface, berdasarkan hasil perhitungan diatas $90.90 \%$ responden memberikan penilaian sangat setuju, $7.27 \%$ responden menjawab setuju dan $1.83 \%$ responden menjawab cukup setuju.

Berdasarkan Tabel 2 dapat dihitung dari keseluruhan indikator untuk memperoleh kesimpulan hasil pengujian. Adapun hasil yang didapatkan adalah sebagai berikut. Berdasarkan hasil perhitungan diatas $89 \%$ responden memberikan penilaian sangat setuju, $10 \%$ responden memberikan nilai setuju dan $1 \%$ responden memberikan nilai cukup setuju.

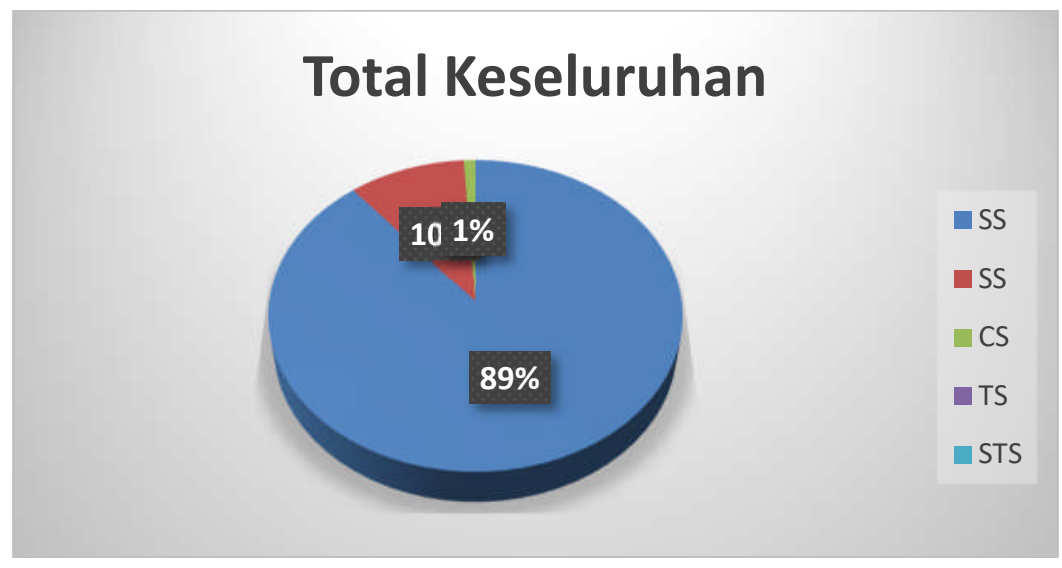

Gambar 10. Kesimpulan Hasil Pengujian

\section{KESIMPULAN}

Dari hasil penelitian yang berjudul Sistem Informasi Pendataan Penduduk Pendatang Pada Kecamatan Tegallalang yang telah dilakukan, maka diperoleh kesimpulan:

Telah berhasil dibangun sebuah sistem informasi pendataan penduduk pendatang kecamatan Tegallalang menggunakan framework Codeigniter, yang berguna untuk mempermudah untuk mendata penduduk pendatang di kecamatan Tegallalang. sistem error.

Hasil pengujian dengan menggunakan metode blackbox testing tidak di temukan adanya

Hasil pengujian dengan menggunakan kuesioner dapat disimpulkan bahwa sistem yang telah dibuat dapat dikatakan efektif dan sudah memenuhi seluruh indikator dengan persentase keseluruhan sebesar $89 \%$ responden memberikan penilaian sangat setuju, $10 \%$ responden memberikan penilaian setuju dan $1 \%$ responden memberikan penilaian cukup setuju.

\section{SARAN}

Sebagai pengembangan selanjutnya dari penelitian yang dilakukan, maka didapat masukan dan beberapa saran dari pendukung penelitian ini, sehingga Sistem Informasi Pendataan Penduduk Pendatang Pada Kecamatan Tegalalang ini menjadi lebih sempurna, adapun saran yang dimaksud adalah sebagai berikut: Sistem ini dapat dikembangkan untuk perangkat mobile atau smartphone seperti Android, IOS, maupun Windows Phone. Pada pengembangan selanjutnya diharapkan adanya tambahan fitur seperti menyempurnakan akurasi lokasi dalam menemukan tempat tinggal penduduk pendatang dengan menggunakan Google Maps 


\section{DAFTAR PUSTAKA}

[1] Iman Hermawan, Pendidikan Bagi Pendatang Di Tengah Mayoritas Masyarakat Pribumi, Mei 2014.

[2] Rini Asmara, S.Kom, M.Kom, Sistem Informasi Pengolahan Data Penanggulangan Bencana Pada Kantor Badan Penanggulangan Bencana Daerah (Bpbd) Kabupaten Padang Pariama, Jurnal J-Click Vol 3 No 2 Desember 2016

[3] Syarifudin Agus, sistem informasi sekolah pada SMK Nurul Huda Pemulutan berorientasi objek : STIMIK PalComTech Palembang 2009

[4] Rinandi Awan Sagita, Hari Sugiarto, Penerapan Metode Waterfall Pada Sistem Informasi Penjualan Furniture Berbasis Web, Oktober 2016

[5] Sulastri, Membangun DataBase Jurnal Ilmiah Berbasis Web Menggunakan Manajemen Data File Teks. 2014 